\title{
In vitro evaluation of nematicidal properties of Solanum sisymbriifolium and S. nigrum extracts on Pratylenchus goodeyi
}

\author{
Margarida PestanA ${ }^{1,2, *}$, Mónica Rodrigues ${ }^{2}$, Lucília TeIXeIrA ${ }^{2}$, \\ Isabel de O. ABRANTES ${ }^{3}$, Manuela Gouveia $^{2}$ and Nereida CORDEIRO ${ }^{4}$ \\ ${ }^{1}$ Madeira Agricultural Laboratory, RAM, 9135-372 Santa Cruz, Portugal \\ ${ }^{2}$ Centre of Life Sciences, University of Madeira, 9000-390 Funchal, Portugal \\ ${ }^{3}$ IMAR-CMA, Department of Life Sciences, University of Coimbra, 3004-517 Coimbra, Portugal \\ ${ }^{4}$ Centre of Exact Science and Engineering, University of Madeira, 9000-390 Funchal, Portugal
}

Received: 2 April 2013; revised: 28 May 2013

Accepted for publication: 28 May 2013; available online: 18 July 2013

\begin{abstract}
Summary - The root-lesion nematode, Pratylenchus goodeyi, is among the most economically damaging parasites of banana plants. Nematode control can benefit from searching for novel bio-nematicides. The present study was carried out to assess the potential nematicidal properties of two Solanum species (Solanum sisymbriffolium and S. nigrum) against $P$. goodeyi, using dichloromethane, acetone, ethanol and either cold or hot water extracts of the plants. Water extracts of both plants at a concentration of $10 \mathrm{mg} \mathrm{ml}^{-1}$ greatly affected nematode movement and also caused mortality. The analysis of sequential extracts at the same experimental concentrations showed that, although water extracts affect nematode mobility and mortality, the acetone extract from $S$. nigrum was the most efficient, causing $100 \%$ mortality after $23 \mathrm{~h}$ exposure. The results showed that S. sisymbriifolium and S. nigrum extracts contain chemical components that induce morphological changes in the body structure of the root-lesion nematode, affect mobility and cause mortality. The nematostatic and nematicidal potential of the extracts described herein merit further studies to find novel bio-nematicides against the root-lesion nematode.
\end{abstract}

Keywords - banana plantation, Musa acuminata, natural nematicide, plant extracts.

Nematodes of the genera Helicotylenchus, Pratylenchus and Rotylenchulus are very common on the island of Madeira. Mixtures of these nematodes can damage the banana culture and subsequently decrease yield and fruit quality. The root-lesion nematode $P$. goodeyi (Cobb) Sher \& Allen, 1953 is considered the most damaging nematode for banana plantations in Canary Islands, Cyprus, Crete and Taiwan (Gowen \& Quénéhervé, 1990; Stover \& Simmonds, 1991; Pinochet et al., 1995), as well as in Madeira (Troccoli et al., 1996).

Pratylenchus goodeyi induces necrotic lesions in roots and pseudostems of banana plants. These nematodes feed, reproduce and migrate within the root tissue, causing necrosis and rotting, thus impairing the root system functions. A weakened root system affects banana plant establishment and anchoring to the soil, making it susceptible to toppling, especially when plants have a banana bunch in the final formation phase or when winds are strong (Speijer et al., 1999; Stoffelen et al., 1999; Gold et al., 2004).
In order to control the nematode populations, farmers use chemical products that contribute to soil, groundwater and atmospheric contamination. Hence, it is imperative to change the agricultural practices associated with banana culture, making them less harmful to the environment and simultaneously enhance food safety and product quality. As plants synthesise a large variety of secondary metabolites with multiple applications, including the control of nematodes (Gommers, 1973; Chitwood, 2002; Osei et al., 2011; Kayani et al., 2012), they can be used either as natural nematicides or as a source of novel compounds.

In this work, two Solanum species were selected, Solanum sisymbriifolium Lam. and S. nigrum L. While the first is a native of warm temperate climates of South America and nowadays is present as an invasive species worldwide (USDA, NRCS, 2007), the latter is a Eurasian species distributed all over the world (Edmonds, 1979; Frohne \& Pfander, 1983; Valdés, 2012). Solanum nigrum

\footnotetext{
* Corresponding author, e-mail: margaridacorreia.sra@gov-madeira.pt
} 
is very common in Madeira, where it blooms throughout the year and can be found in cultivated land, in walls and along the roads, appearing spontaneously in the banana plantations. Although $S$. sisymbriifolium is absent from Madeira, it has been successfully used elsewhere to control populations of potato-cyst nematodes, Globodera spp., promoting the hatching of second-stage juveniles that invade its roots in large numbers but are unable to complete their life cycle (Scholte, 2000a, b).

The chemical constituents of Solanum spp. have been described as steroidal glycosides, alkaloids and oligoglycosides, flavonoids and triperpenoids (Eltayeb et al., 1997; Ikeda et al., 2000; Raju et al., 2003; Heo et al., 2004; Cai et al., 2010). Several pharmacological and toxicological studies of these compounds have revealed their broad spectrum of activity as, for example, against human tumours, cancer chemopreventive, antihepatotoxic, antineoplastic, and with antiviral and antioxidant properties among others (Kumar et al., 2001; Heo et al., 2004; Zhou et al., 2006; Jeong et al., 2007; Lin et al., 2007, 2008; Ji et al., 2008; Cai et al., 2010). Solanum nigrum is widely used in popular medicine and it is also believed to have therapeutic properties against some types of tumours since some compounds showed cytotoxic effects in tumour cells (Zhou et al., 2006) and cancer preventive cells (Jeong et al., 2007).

Previous studies (Pestana et al., 2009) revealed that $S$. sisymbriifolium and $S$. nigrum are not suitable or non-hosts for $P$. goodeyi and the incorporation of these plants into soil benefits the growth of banana plants either by direct action, through the release of exudates with nematicidal effect, and/or by an indirect contribution, promoting the development of antagonists and making the rhizosphere unfavourable to the nematode. In addition, it was found that mobility of $P$. goodey $i$ was affected by the components extracted in water at the quantities corresponding to the initial concentration of dry and fresh extracts from both plants. Furthermore, these extracts were effective in nematode mortality as after 10 days of exposure all nematodes were dead (Pestana et al., 2010). Therefore, this study aims to expand the knowledge of these plants by evaluating the nematicidal properties of extracts from fresh and dried plants. These extracts were tested in vitro for their toxicity against $P$. goodeyi to disclose its effectiveness as a first attempt to identify constituents exhibiting nematicidal activity.

\section{Materials and methods}

\section{PLANT MATERIAL}

Solanum sisymbriifolium Pion seeds were provided by Vandijke Semo Seed and Services, and S. nigrum plants were obtained from natural habitats and kept in the laboratory for the production of fruits and seeds.

Seeds of both plants were germinated in sterile peat and the plants were maintained in a glasshouse until they reached 50-60 $\mathrm{cm}$ height. They were then collected and divided into two samples: one was weighed and frozen for further analysis (named fresh plant) and the other was placed in a ventilated drying chamber at $30^{\circ} \mathrm{C}$ (named dry plant). The dry plants were ground in a cutting mill (Arthur H. Thomas) and passed through sieves of 40 and 60 mesh (Retsch). The 40-60 mesh size fraction (425$250 \mu \mathrm{m}$ ) was used for the extractions. The water content in the samples was determined on a moisture balance (Gibertini-Eurotherm).

\section{WATER EXTRACTIONS}

Two methods were used to obtain the water extracts: blender and reflux. In the blender method, S. sisymbriifolium and $S$. nigrum were extracted in water at a ratio of $1: 4$ or $1: 20(\mathrm{w} / \mathrm{v}$, material/water) of fresh plant or dry plant, respectively. The plant material was gently shaken in water, ground for $10 \mathrm{~min}$ in the blender and filtered (using a G4 filter, pore size $10-16 \mu \mathrm{m}$ ). This procedure was performed using water either at room temperature (cold water) or boiling (hot water).

The same material/water ratio was used in the reflux extraction. The plant material was refluxed during $1 \mathrm{~h}$ and the liquid fraction was obtained after filtration through a G4 filter.

All extracts were lyophilised, quantified and stored at $-20^{\circ} \mathrm{C}$ in the dark until further analysis. Five determinations were performed and the results were expressed as a percentage of the extract in dry matter in relation to the original plant weight used in the extraction.

\section{SEQUENTIAL EXTRACTION}

Dry $S$. sisymbriifolium and S. nigrum plants were subjected to a Soxhlet sequential extraction with dichloromethane, acetone and ethanol during $10 \mathrm{~h}$ in each solvent. Each extraction solution was dried by vacuum evaporation at $40^{\circ} \mathrm{C}$ until constant weight. Each solvent was completely evaporated and the solid residue recovered. The extract percentage was determined gravimetrically. 
After ethanol extraction, the plant material was dried at $30^{\circ} \mathrm{C}$. The dried material was refluxed for $1 \mathrm{~h}$ in water to obtain the remaining extracts in water. After filtration (G4 filter), the water extract was lyophilised and gravimetrically quantified. All extracts were stored as mentioned before.

All reagents used in this work, namely dichloromethane, acetone and ethanol, were chromatographic grade (Merck, Sigma-Aldrich or Fluka).

\section{PRATYLENCHUS GOODEYI ISOLATES}

Twenty-eight samples of soil and banana roots were collected on the southern coast of Madeira. The rootlesion nematode isolates were multiplied on banana plants obtained from in vitro culture. The nematodes were extracted from soil by centrifugal flotation using the sucrose method (Jenkins, 1964; Abrantes et al., 1976) and from roots by the maceration and sieving method (Abrantes et al., 1976; Hooper, 1986). The identification of $P$. goodeyi isolates based on morphological characters was done in the Istituto per la Protezione delle Piante Sezione di Bari, Italy.

\section{NEMATICIDAL ACTIVITY}

Each solid residue $(10 \mathrm{mg})$ was dissolved in water $(1 \mathrm{ml})$ and the aqueous solution containing water soluble compounds tested for activity against $P$. goodeyi. The bioassays were conducted using $1 \mathrm{ml}$ of each extract solution in a syracuse watchglass containing ten adult $P$. goodeyi, and left in the dark at room temperature ( $25 \pm$ $1^{\circ} \mathrm{C}$ ) for 10 days. Each treatment was replicated five times and sterile distilled water was used as control. The effect of acetone extract on nematode mortality was assessed during a period of $24 \mathrm{~h}$. The bioassay was repeated once as a biological replicate. The nematodes were observed daily using a binocular microscope and numbers of inactive or dead nematodes were recorded. Nematodes were considered dead when after being transferred to sterile water for $2 \mathrm{~h}$ and stimulated by prodding they remained inactive.

\section{STATISTICAL ANALYSIS}

Statistical analyses were performed using the SPSS (Statistical Package for the Social Sciences) 15.0 software for Windows. Registered mortality was converted into cumulative mortality and corrected by Abbott's (1925) formula prior to analysis. The values obtained for nematode mortality were analysed to verify if they have a normal distribution by normality tests of KolmogorovSmirnov and Shapiro-Wilk $(P>0.05)$. One-way analysis of variance (ANOVA) was used to find significant differences on the mortality of $P$. goodeyi using $S$. sisymbriifolium and $S$. nigrum extracts. In addition, Tukey's test was used for multiple comparisons of means. The statistical test was run independently for each treatment and plant species.

\section{Results}

\section{WATER EXTRACTS}

The extracts obtained through the blender method either with cold or hot water and through the reflux method, ranged from $7.53 \%$ for $S$. sisymbriifolium cold fresh plant to $12.42 \%$ for $S$. nigrum reflux fresh plant (Table 1). In general, extractions by reflux showed a higher content, while the cold water blender extraction was the least efficient in the extraction process. According to ANOVA, no differences $(P>0.05)$ were observed between the use of fresh and dry plant. However, in $S$. sisymbriifolium the extract content was slightly higher in dry plant material, whereas in $S$. nigrum the higher extract quantities were obtained when fresh plant material was used.

\section{SEQUENTIAL EXTRACTS}

The water fraction yielded the highest amount of extract, whereas acetone had the smallest value $(2 \%)$ for each plant species (Table 2). Components extracted from S. nigrum in dichloromethane and acetone were five- and 13-fold lower, respectively, than the components extracted in ethanol and water.

The content of extracts obtained in water sequential extraction was two- to three-fold higher than those in water extraction from the dry and fresh plants. This discrepancy might be due to the previous solvent used (dichloromethane, acetone and ethanol) before the final water extraction, which could either increase the destruction of plant cells or promote the accessibility/solubility of chemical components.

\section{NEMATICIDAL ACTIVITY OF WATER EXTRACTS}

Pratylenchus goodeyi progressively reduced mobility in water extracts obtained from fresh and dry plant of 
Table 1. Extracts (\% of dry matter) obtained from Solanum sisymbriifolium and S. nigrum blended in hot and cold water or by reflux.

\begin{tabular}{lrrrr}
\hline Water extract & \multicolumn{2}{c}{ S. sisymbriifolium } & \multicolumn{2}{c}{ S. nigrum } \\
\cline { 2 - 3 } & Fresh plant & Dry plant & Fresh plant & Dry plant \\
\hline Cold & $7.53 \pm 0.24$ & $8.78 \pm 0.41$ & $9.09 \pm 0.11$ & $7.65 \pm 1.26$ \\
Hot & $7.78 \pm 0.15$ & $11.20 \pm 1.32$ & $11.75 \pm 0.40$ & $9.26 \pm 0.48$ \\
Reflux & $8.83 \pm 0.20$ & $11.81 \pm 0.09$ & $12.42 \pm 0.27$ & $10.02 \pm 0.94$ \\
\hline
\end{tabular}

Results are the mean of five replicates (mean \pm S.D.).

Table 2. Extracts (\% of dry matter) obtained from Solanum sisymbriifolium and $S$. nigrum dry plants using sequential extraction.

\begin{tabular}{lrr}
\hline Sequential extract & S. sisymbrifolium & \multicolumn{1}{c}{ S. nigrum } \\
\hline Dichloromethane & $4.02 \pm 0.09$ & $3.52 \pm 0.09$ \\
Acetone & $2.05 \pm 0.12$ & $2.04 \pm 0.12$ \\
Ethanol & $17.28 \pm 0.74$ & $18.73 \pm 0.63$ \\
Water & $22.97 \pm 0.23$ & $25.97 \pm 1.42$ \\
\hline
\end{tabular}

Results are the mean of five replicates (mean \pm S.D.).

S. sisymbriifolium; up to the eighth day of exposure few differences were observed between the two extracts. $\mathrm{Cu}-$ mulative mortality analysis showed that for S. sisymbriifolium the differences between fresh and dry plant were not significant, both extracts being effective on nematode mortality (Fig. 1).

In the fresh and dry plant extracts of $S$. nigrum, lack of nematode mobility was observed as early as the second day and recovery of nematode mobility, tested on sterile water, diminished thereafter (Fig. 2), but in the dry cold extract a less pronounced reduction of mobility was found. In $S$. nigrum, no significant differences in $P$. goodeyi mortality were found by Tukey multiple comparison test $(P>0.05)$ for water extracts from fresh plant, all extracts being equally effective on nematode mortality (Fig. 3A). Nevertheless, significant differences were detected between hot and cold water extracts from dry S. nigrum plants (Fig. 3B). Dry cold water extracts were less effective on nematode mortality (Fig. 3B). Thus, it is apparent that the potential nematicidal compounds of $S$. nigrum are more accessible either in fresh plants or when dried material is submitted to hot extractions.

Another relevant aspect observed in most of the water extracts from both plants is that the majority of dead nematodes had a mostly straight or only slightly bent body shape with few showing a sigmoid shape (Fig. 2A).
These results indicate that water extracts from Solanum plants may contain one or more compounds that affect nematodes and differences observed in the nematicidal activity from these extracts are possibly due to their composition and extraction method.

\section{NEMATICIDAL ACTIVITY OF SEQUENTIAL EXTRACTS}

Pratylenchus goodeyi subjected to sequential extracts obtained from both plant species revealed significant differences in their activity (Fig. 4). Nematode mobility was little affected in dichloromethane and ethanol extracts. A clear drop in nematode activity was observed in acetone and water extracts.

The effect of dichloromethane extracts on nematode mortality was not statistically significant. Moreover, the $S$. nigrum dichloromethane extract did not seem to be toxic as little loss of nematode mobility and low mortality was recorded in this extract at the concentration of $10 \mathrm{mg}$ $\mathrm{ml}^{-1}$ (Fig. 4B). Acetone and water extracts were the most effective, with the acetone extract causing more than $95 \%$ cumulative mortality on the second day of exposure. The higher percentage of $P$. goodeyi mortality in the acetone and the water extract, after the solvent sequence, might suggest that either the active nematicidal components were not separated in the initial solvent or negligible amounts were present in less polar extracts.

After the first hours of exposure to acetone extracts, nematode movements became slower and morphological changes in the body structure were detected such as a separation between the cuticle and internal content of the body, some rigidity, necrosis of tissues and partial disintegration of internal organs (Fig. 5). Exposure to the acetone and water extracts resulting from sequential extraction led to more than $85 \%$ of nematodes dying with a mostly straight or slightly bent body shape, with few $( \pm 15 \%)$ showing a sigmoid shape, as checked in water extracts from single extraction (Fig. 2A). In 

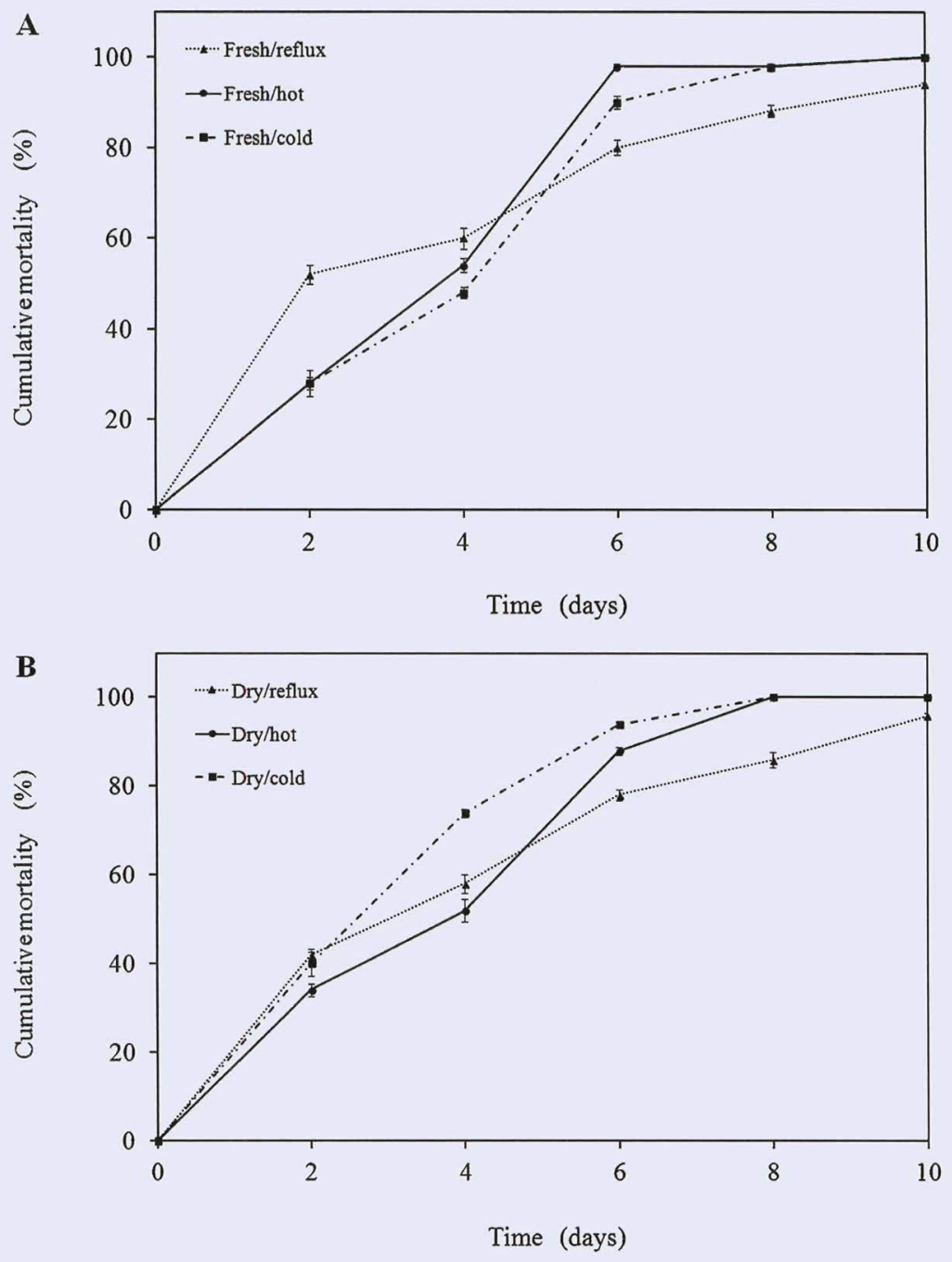

Fig. 1. Cumulative mortality of Pratylenchus goodeyi in cold, hot and reflux water extracts at $10 \mathrm{mg} \mathrm{ml}^{-1}$ concentration from fresh (A) and dry (B) Solanum sisymbriifolium. Each time point represents the average of five replicates and vertical bars represent standard deviation among replicates. The cumulative effect for water extracts is not significantly different $(P>0.05)$ according to the ANOVA.
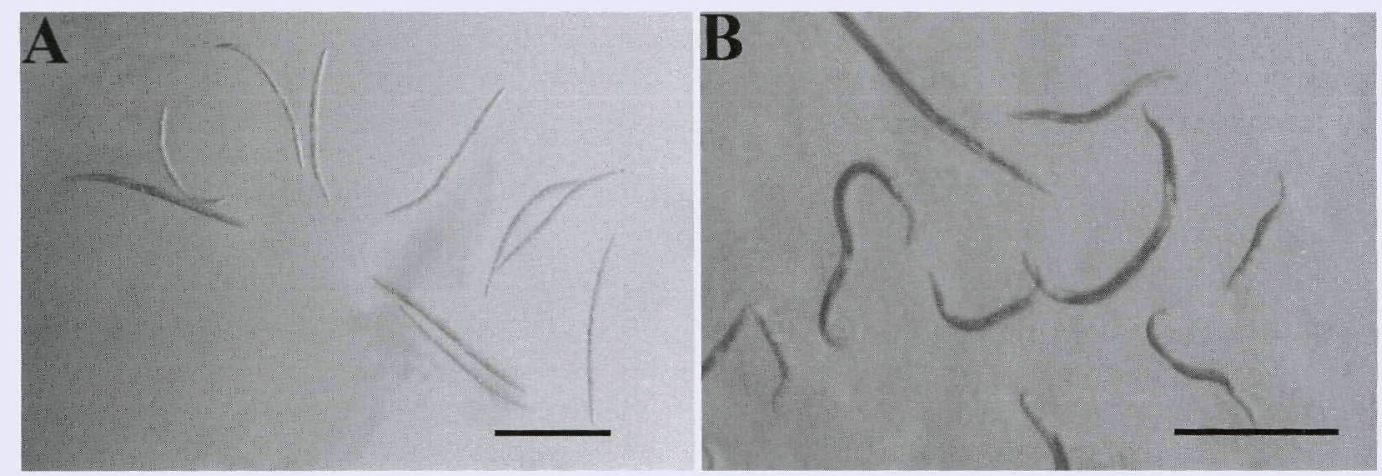

Fig. 2. Activity of Pratylenchus goodeyi after 2 days in water extracts from fresh Solanum nigrum at $10 \mathrm{mg} \mathrm{ml}^{-1}$ plant concentration (A) and in water as control (B). (Scale bars $=300 \mu \mathrm{m}$.) 

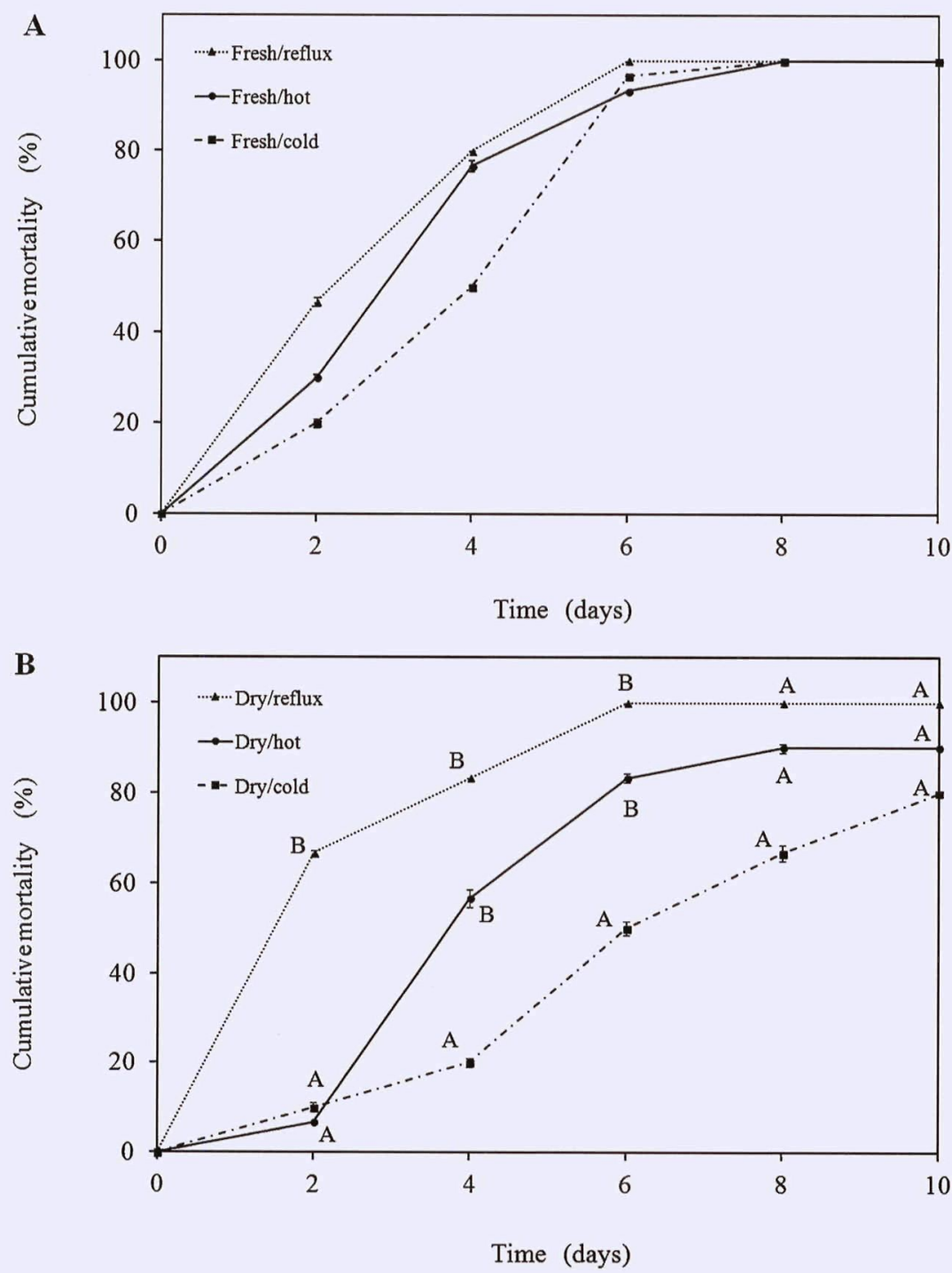

Fig. 3. Cumulative mortality of Pratylenchus goodeyi in cold, hot and reflux water extracts, at $10 \mathrm{mg} \mathrm{ml}^{-1}$ concentration, from fresh (A) and dry (B) Solanum nigrum. Each time point represents the average of five replicates and vertical bars represent standard deviation among replicates. The same letter at each time indicates that values are not different $(P>0.05)$ according to Tukey's multiple comparison test.

dichloromethane and ethanol extracts, nematodes were found with straight, bent and sigmoid body shape but also some with a curled body shape, most common in the ethanol extract. The efficiency of acetone extract from S. nigrum on nematode mortality recorded over a $24-\mathrm{h}$ period revealed that nematode immobility was evident after the first hour of exposure. The mortality of $P$. goodey $i$ was more pronounced after $15 \mathrm{~h}$ of exposure ( $\mathrm{ca} 50 \%$ ), and at the end of the experiment all nematodes had died (Fig. 6).

\section{Discussion}

Strong evidence for the role of some of the components present in S. sisymbriifolium and S. nigrum plants against $P$. goodeyi were found. Plant extracts from both Solanum plants affect $P$. goodeyi mobility and cause mortality, suggesting that compounds with nematostatic or nematicidal properties are present. In fact, it is well known that plants of the family Solanaceae are sources of secondary metabolites which act as bioactive compounds, 

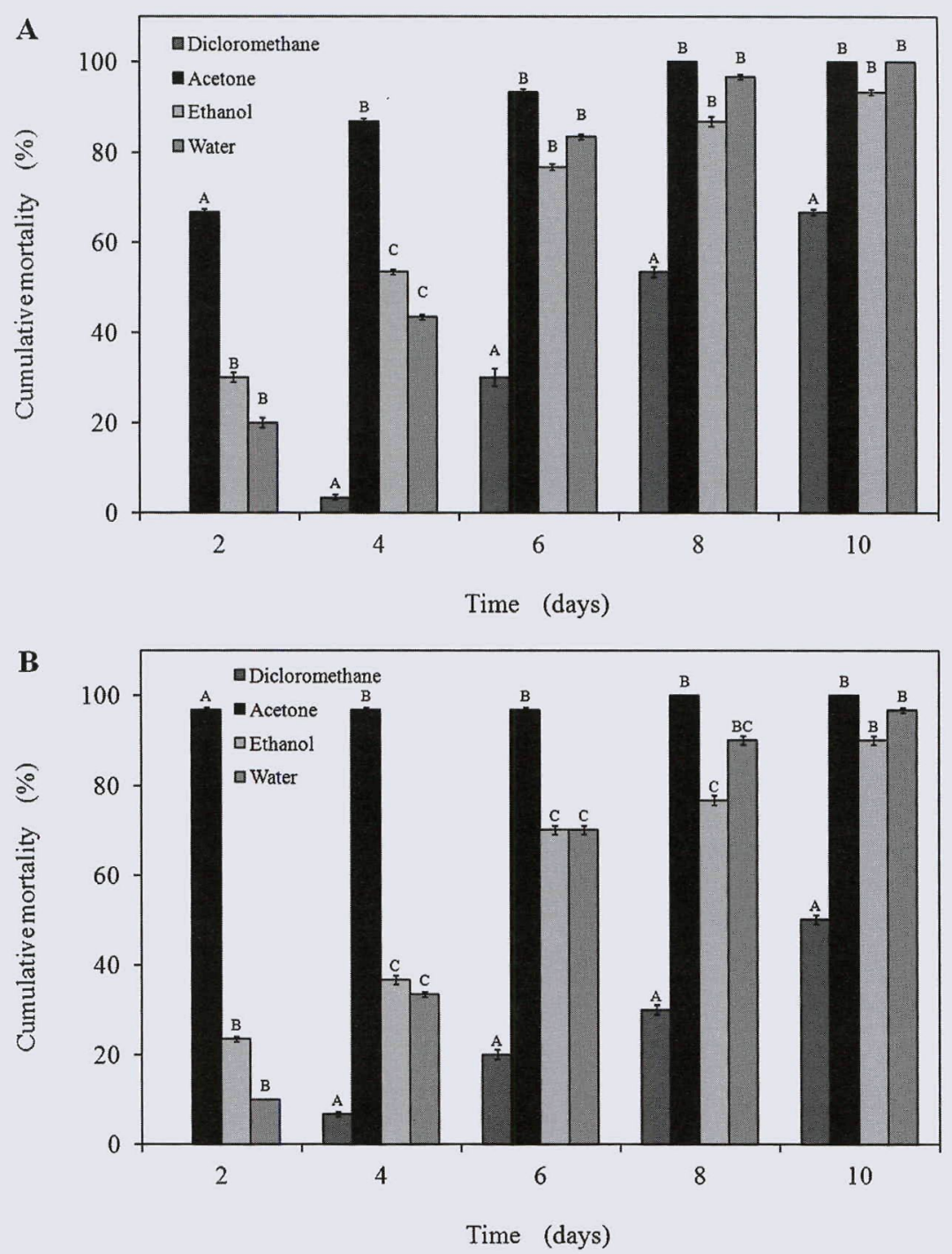

Fig. 4. Cumulative mortality of Pratylenchus goodeyi in dicloromethane, acetone, ethanol and water extracts at $10 \mathrm{mg} \mathrm{ml}^{-1}$ concentration, from Solanum sisymbriifolium (A) and S. nigrum (B). Results are five replicates means and vertical bars represent standard deviation among replicates. The same letter at each time indicates that they are not different $(P>0.05)$ according to Tukey's multiple comparison test.

such as alkaloids, flavonoids and saponins that have a broad spectrum of activity (Evans et al., 1984; Eltayeb et al., 1997; Zhou et al., 2006; Ono et al., 2009; Cai et al., 2010).

The water extracts obtained from dry and fresh plants demonstrated the same efficacy on $P$. goodeyi mortality as the water extracts from the sequential solvent extraction. Total lack of mobility and $100 \%$ of mortality after exposure to water extracts at initial concentration and at the concentration of $10 \mathrm{mg} \mathrm{m}^{-1}$ for Solanum plants was previously reported (Pestana et al., 2011), and these results were consistent with those obtained by Haseeb \& Butoll (1996) for S. nigrum. It is expected that several nitrogen-rich compounds, glycosides, alkaloids, saponins, tannins and terpenoids (Tiwari et al., 2011) are extracted in water and many of these compounds act against nematodes (Chitwood, 2002). Therefore, it is likely that one or more of such compounds could be changing the nematode activity and may be the cause of the observed mortality. 

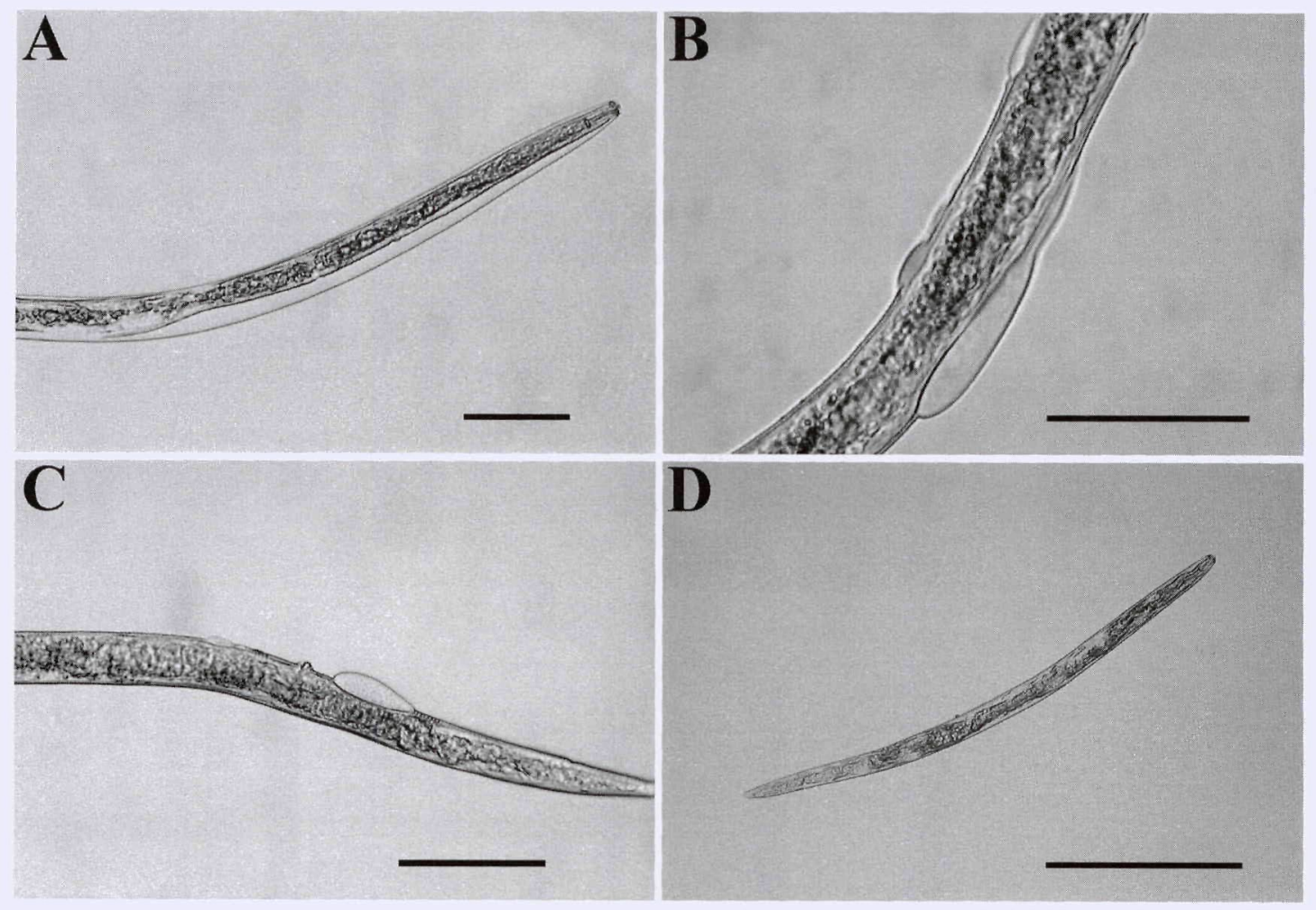

Fig. 5. Morphological changes of Pratylenchus goodeyi in Solanum nigrum acetone extract. Separation is evident between the cuticle and internal content of the body (A, B and C). Condensation, rigidity and necrosis of tissues occurs (D). (Scale bars: A, C = 50 $\mu$ m; $\mathrm{B}=40 \mu \mathrm{m} ; \mathrm{D}=200 \mu \mathrm{m}$.)

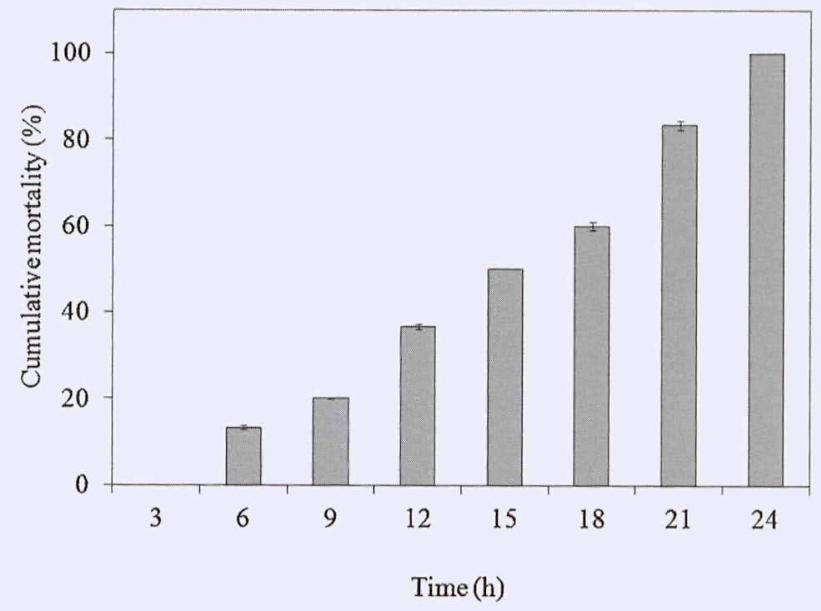

Fig. 6. Mortality of Pratylenchus goodeyi over 24-h incubation in Solanum nigrum acetone extract $\left(10 \mathrm{mg} \mathrm{ml}^{-1}\right)$. Each time point represents the average of five replicates and vertical bars represent standard deviation among replicates.

The acetone solvent should extract phenolics, flavonoids, saponins and some pyrethroids compounds (So- brinho et al., 2010; Tiwari et al., 2011). In fact, the mobility of $P$. goodey $i$ was affected mainly by the $S$. nigrum acetone extract from the first day of exposure, a feature that can be also observed through the morphological changes that were found in the bodies of nematodes subjected to this extract. These results showed that, compared with the other solvents, the acetone extract, at a concentration of $10 \mathrm{mg} \mathrm{ml}^{-1}$ in relation to the initial concentration (data not shown), may have nematicidal compounds that act synergistically on nematode mortality.

In water and acetone sequential extracts of both Solanum plants a large percentage of nematodes died with a body shape mostly straight or slightly bent, with very few showing a sigmoid shape and none curled as was obtained in the fresh and dry plant extracts. The changes in the body shape of nematodes might be assigned to the toxic effect of pyrethroids, well-known insecticides that directly affect the central nervous system (Santos et al., 2007). According to Wiratno et al. (2009), the pyrethroid-like action resulted in dead nematodes that never had curly shapes but were mostly bent or 
straight and very few sigmoid, and this effect is consistent with our results. Furthermore, among the groups of compounds that may be found in both the acetone and the water extracts, it is well known that alkaloids affect the central nervous system causing paralysis and that saponins generally cause vacuolation and disintegration of the integument and alteration of membrane permeability. Therefore, it can be assumed that the mobility behavioural and morphological changes observed are related to the toxic effect of the extracts assayed.

As reported previously (Pestana et al., 2009), S. sisymbriifolium and $S$. nigrum do not host $P$. goodeyi but the incorporation of these plants into the soil benefited banana plant growth and decreased the nematode reproduction factor. It was hypothesised that a direct action through the release of exudates with nematicidal effect or an indirect contribution through the promotion of antagonists would make the rhizosphere unfavourable to the nematode. Altogether, the results showed the nematicidal potential of these Solanum plants and especially that $S$. nigrum, easily accessible to farmers, can be incorporated into the soil or used between banana plants.

In conclusion, the water and acetone extracts of $S$. sisymbriifolium and $S$. nigrum are shown to have in their composition components that possess nematostatic or nematicidal activity against $P$. goodeyi and these effects are irreversible. It is clear that $S$. nigrum has the greatest effect on nematode mobility and mortality. For this reason we believe that further studies are worthwhile to identify and characterise the active component(s) to be used as environmentally friendly nematicides for plant-parasitic nematodes.

\section{Acknowledgements}

M.P. thanks CITMA for the award of a Doctoral grant (Project No. 001080/2010/132). We thank N. Vovlas from L'Istituto per la Protezione delle Piante Sezione di Bari, Italy, for the identification of $P$. goodeyi and S. Costa from the Department of Botany, University of Coimbra, Portugal, for a critical review of the manuscript.

\section{References}

Abbott, W.S. (1925). A method of computing the effectiveness of an insecticide. Journal of Economic Entomology 18, 265267.
Abrantes, I.M. de O., Morais, M.N. de, Paiva, I.M.P. de F.R. \& Santos, M.S.N. de A. (1976). Análise nematológica de solos e plantas. Ciência Biológica (Portugal) 1, 39-155.

Cai, X.-F., Chin, Y.-W., Oh, S.-R., Kwon, O.-K., Ahn, K.-S. \& Lee, H.-K. (2010). Anti-inflammatory constituents from Solanum nigrum. Bulletin of the Korean Chemical Society 31 , 199-201.

Chitwood, D.J. (2002). Phytochemical based strategies for nematode control. Annual Review of Phytopathology 40, 221249.

De Waele, D. \& Elsen, A. (2002). Migratory endoparasites Pratylenchus and Radopholus species. In: Starr, J.L., Cook, R. \& Bridge, J. (Eds). Plant resistance to parasitic nematodes. Wallingford, UK, CAB International, pp. 175-206.

Edmonds, J.M. (1979). Nomenclatural notes on some species of Solanum L. found in Europe. Botanical Journal of the Linnean Society 78, 213-233.

Eltayeb, E.A., Al-Ansari, A.S. \& Roddick, J.G. (1997). Changes in the steroidal alkaloid solasodine during development of Solanum nigrum and Solanum incanum. Phytochemistry 46, 489-494.

Evans, P.H., Bowers, W.S. \& Funk, E.J. (1984). Identification of fungicidal and nematicidal components in the leaves of Piper betle (Piperaceae). Journal of Agricultural and Food Chemistry 32, 1254-1256.

Frohne, D. \& Pfander, H.J. (1983). A colour atlas of poisonous plants: a handbook for pharmacists, doctors, toxicologists and biologists. London, UK, Wolfe Publishing.

Gold, C.S., Kagezi, G.H., Night, G. \& Ragama, P.E. (2004). The effects of banana weevil, Cosmopolites sordidus (Germar), damage on highland banana growth, yield and stand duration in Uganda. Annals of Applied Biology 145, 263-269.

Gommers, F.J. (1973). Nematicidal principles in Compositae. Wageningen, The Netherlands, Mededelingen Landbouwhogeschool, pp. 71-73.

Gowen, S. \& Quénéhervé, P. (1990). Nematode parasites of bananas, plantains and abaca. In: Luc, M., Sikora, R.A. \& Bridge, J. (Eds). Plant-parasitic nematodes in subtropical and tropical agriculture. Wallingford, UK, CAB International, pp. 431-460.

Haseeb, A. \& Butool, F. (1996). Evaluation of nematicidal properties of some members of the family Solanaceae. Bioresource Technology 57, 95-97

Heo, K.S., Lee, S.J., Ko, J.H., Lim, K. \& Lim, K.T. (2004). Glycoprotein isolated from Solanum nigrum L. inhibits the DNA-binding activities of NF- $\kappa \mathrm{B}$ and AP-1, and increases the production of nitric oxide in TPA-stimulated MCF-7 cells. Toxicology in Vitro 18, 755-763.

Hooper, D.J. (1986). Extraction of nematodes from plant material. In: Southey, J.F. (Ed.). Laboratory methods for work with plant and soil nematodes. London, UK, Her Majesty's Stationery Office, pp. 51-58. 
Ikeda, T., Tsumagari, H. \& Nohara, T. (2000). Steroidal oligoglycosides from Solanum nigrum. Chemical and Pharmaceutical Bulletin 48, 1062-1064.

Jenkins, W.R. (1964). A rapid centrifugal-flotation technique for separating nematodes from soil. Plant Disease Reporter 48, 692.

Jeong, J.B., Jeong, H.J., Park, J.H., Lee, S.H., Lee, J.R., Lee, H.K., Chung, G.Y., Choi, J.D. \& de Lumen, B.O. (2007). Cancer-preventive peptide lunasin from Solanum nigrum L. inhibits acetylation of core histones $\mathrm{H} 3$ and $\mathrm{H} 4$ and phosphorylatin of retinoblastoma protein $(\mathrm{Rb})$. Journal of Agriculture and Food Chemistry 55, 10707-10713.

Ji, Y.B., Gao, S.Y., Ji, C.F. \& Zou, X. (2008). Induction of apoptosis in Hepg2 cells by solanine and Bcl-2 protein. Journal of Ethno-Pharmacology 115, 194-202.

Kayani, M.Z., Mukhtar, T. \& Hussain, M.A. (2012). Evaluation of nematicidal effects of Cannabis sativa L. and Zanthoxylum alatum Roxb. against root-knot nematodes Meloidogyne incognita. Crop Protection 39, 52-56.

Kumar, V.P., Shashidhara, S., Kumar, M.M. \& Sridhara, B.Y. (2001). Cytoprotective role of Solanum nigrum against gentamicin-induced kidney cell (Vero cells) damage in vitro. Fitoterapia 72, 481-486.

Lin, H.M., Tseng, H.C., Wang, C.J., Chyau, C.C., Liao, K.K., Peg, P.L. \& Chou, F.P. (2007). Induction of autophagy and apoptosis by the extract of Solanum nigrum Linn HepG2 cells. Journal of Agriculture and Food Chemistry 55, 36203628.

Lin, H.M., Tseng, H.C., Wang, C.J., Lin, J.J., Lo, C.W. \& Chou, F.P. (2008). Hepatoprotective effects of Solanum nigrum Linn extract against CCl4-induced oxidative damage in rats. Chemico-Biological Interactions 171, 283-293.

Ono, M., Kakiuchi, T., Ebisawa, H., Shiono, Y., Nakamura, T.K., Ikeda, T., Miyashita, H., Yoshimitsu, H. \& Nohara, T. (2009). Steroidal glycosides from the fruits of Solanum viarum. Chemical and Pharmaceutical Bulletin 57, 632-635.

Osei, K., Addico, R., Nafeo, A., Edu-kwarteng, A., Agyemang, A., Danso, Y. \& Sackey-Asante, J. (2011). Effect of some organic waste extracts on hatching of Meloidogyne incognita eggs. African Journal of Agricultural Research 6, 2255-2259.

Pestana, M., Gouveia, M. \& Abrantes, I.M. de O. (2009). Efeitos de Solanum sisymbriifolium e $S$. nigrum sobre o nemátodedas-lesões-radiculares, Pratylenchus goodeyi, parasita da bananeira. Revista de Ciências Agrárias 32, 174-181.

Pestana, M., Rodrigues, M., Teixeira, L., Abrantes, I.M. de O., Gouveia, M. \& Cordeiro, N. (2010). Nematicidal activity of Solanum sisymbriifolium and S. nigrum extracts against the root-lesion nematode Pratylenchus goodeyi. In: MendezVilas, A. (Ed.). Microoganisms in industry and environmentfrom scientific and industrial research to consumer products. Singapore, World Scientific Publishing, pp. 81-85.

Pinochet, J., Fernandez, C. \& Sarah, J.-L. (1995). Influence of temperature on in vitro reproduction of Pratylenchus coffeae,
P. goodeyi and Radopholus similis. Fundamental and Applied Nematology 18, 391-392.

Raju, K., Anbuganapathi, G., Gokulakrishnan, V., Rajkapoor, B., Jayakar, B. \& Manian, S. (2003). Effect of dried fruits of Solanum nigrum Linn against $\mathrm{CCl} 4$-induced hepatic damage in rats. Biological and Pharmaceutical Bulletin 26, 16181619.

Santos, M.A.T. dos, Areas, M.A. \& Reyes, F.G.R. (2007). Piretróides-uma visão geral. Alimentos e Nutrição 18, 339349.

Scholte, K. (2000a). Screening of non-tuber bearing Solanaceae for resistance to and induction of juvenile hatch of potato cyst nematodes and their potential for trap cropping. Annals of Applied Biology 136, 239-246.

Scholte, K. (2000b). Growth and development of plants with potential for use as trap crops for potato cyst nematodes and their effects on the numbers of juveniles in cysts. Annals of Applied Biology 137, 031-042.

Sher, S.A. \& Allen, M.W. (1953). Revision of the genus Pratylenchus (Nematoda: Tylenchidae). University of California Publications in Zoology 57, 441-469.

Sobrinho, T.J. das. P., Gomes, T. de L.B., Cardoso, K.C. de M. \& Amorim, E.L.C. de (2010). Otimização de metodologia analítica para o doseamento de flavonoides de Bauhinia cheilantha (Bongard) Steudel. Quimica Nova 33, 288-291.

Speijer, P.R., Kajumba, C. \& Ssango, F. (1999). East African highland banana production as influenced by nematodes and crop management in Uganda. International Journal of Pest Management 45, 41-49.

Stoffelen, R., Jimenez, M.I., Dierckxsens, C., Tam, V.T.T., Swennen, R. \& De Waele, D. (1999). Effect of time and inoculum density on the reproductive fitness of Pratylenchus coffeae and Radopholus similis populations on carrot disks. Nematology 1, 243-250.

Stover, R. \& Simmonds, N.W. (1987). Bananas. Harlow, UK, Longman Scientific and Technical.

Tiwari, P., Kumar, B., Kaur, M., Kaur, G. \& Kaur, H. (2011). Phytochemical screening and extraction: a review. Internationale Pharmaceutica Sciencia 1, 98-106. www.ipharmsciencia.com.

Troccoli, A., Pestana, M., Vovlas, N., Abrantes, I.M. de O. \& Santos, M.S.N. de A. (1996). Endoparasitic nematode species, Pratylenchus goodeyi, from banana root in Madeira island orchards. Second Symposium on the Fauna and Flora of the Atlantic Islands, 12-16 February 1996, Las Palmas de Gran Canaria, pp. 227. [Abstr.]

USDA, NRCS (2007). Solanum sisymbriifolium. The plants database (http://plants.usda.gov, 25 July 2007). Baton Rouge, LA, USA, National Plant Data Center (accessed 6 December 2012).

Valdés, B. (2012). Solanaceae. In: Euro+Med Plantbase - the information resource for Euro-Mediterranean plant diversity. Available online at http://ww2.bgbm.org/EuroPlusMed/ (accessed 6 December 2012). 
Wiratno, Taniwiryono, D., Van den Berg, H., Riksen, J.A.G., Rietjens, I.M.C.M., Djiwanti, S.R., Kammeng, J.E. \& Murk, A.J. (2009). Nematicidal activity of plant extracts against the root-knot nematode Meloidogyne incognita. The Open Natural Products Journal 2, 77-85.
Zhou, X., He, X., Wang, G., Gao, H., Hou, G., Zhou, G., Ye, W. \& Yao, X. (2006). Steroidal saponins from Solanum nigrum. Journal of Natural Products 69, 1158-1163. 
Copyright of Nematology is the property of Brill Academic Publishers and its content may not be copied or emailed to multiple sites or posted to a listserv without the copyright holder's express written permission. However, users may print, download, or email articles for individual use. 